\title{
Legislation
}

\section{In need of a fresh start: gender equality in post-GFA Northern Ireland}

\author{
MiCHeLle Rouse
}

Transitional Justice Institute, University of Ulster

\begin{abstract}
A lmost 20 years after the 1998 Good Friday Agreement (GFA), ${ }^{1}$ evidence suggests that A decision-making in Northern Ireland remains a relatively closed process. ${ }^{2}$ Despite the pledge of equal participation of women in public life, women have remained largely marginalised in this regard and, in particular, remain systemically excluded from positions of power and influence. ${ }^{3}$ The chronic under-representation of women in public life coincides with the development of an increasingly regressive legal and political discourse in respect of women's agency in the legislature and in the courts. ${ }^{4}$ Against this backdrop, the number of women elected to the Northern Ireland Assembly (NIA) lags well behind other devolved institutions. ${ }^{5}$
\end{abstract}

This occurs against an evolving normative international and regional framework ${ }^{6}$ which acknowledges that, in the absence of the active participation of women, the goals of equality, development and peace cannot be achieved. ${ }^{7}$

In that context, this brief evaluation of specimen commitments falling within thematic parameters shines a spotlight on the significant failing of Northern Ireland's world-renowned peace process - to address the post-conflict needs of women.

1 The Agreement: Agreement Reached in the Multi-Party Negotiations (NIO Belfast 1998).

2 Assembly and Executive Review Committee, Report on Women in Politics and the Northern Ireland Assembly (NIA 2015).

3 Women comprise 19 per cent of chairs of public bodies and 33 per cent of public appointments in total. Women comprise 80 per cent of those in part-time employment. A mere 18 per cent of County Court judges are female and, until two appointments in 2015 , there were no female members of the judiciary at more senior rank. There are currently no female permanent secretaries within the Northern Ireland Civil Service and at grade 5 and above only 33 per cent of staff are women. In education, there are no female University Vice Chancellors: Michael Potter, 'Who Runs Northern Ireland? A Summary of Statistics relating to Gender and Power' Research and Information Service Briefing Paper 79/14 (NIA 2014).

4 Northern Ireland Human Rights Commission v Department of Justice for Northern Ireland [2015] NIQB 96; NIA, Official Report (Hansard) Wednesday 10 February, 2016, vol 112, no 5, 77-120.

5 Women comprise 48 per cent of the Welsh Assembly and 35 per cent of the Scottish Parliament: Suzanne Breen, 'Record Number of Women MLAs returned to Stormont' Belfast Telegraph (Belfast, 9 May 2016).

6 UNSC Res 1325 (31 October 2000) UN DOC S/RES/1325. See also wider WPS agenda, CEDAW General Recommendation No 30 (18 October 2013) CEDAW/C/GC/30.

7 Beijing Declaration and Platform for Action, Fourth World Conference on Women, 15 September 1995 A/conf.177/20 (1995) endorsed by GA Res 50/203, 22 December 1995. 
While fractured momentum may be typically observed within peace processes, ${ }^{8}$ in the case of Northern Ireland, an unquestioning approach to this rationale risks imparting the impression of 'inevitability'. In so doing, it may serve to obscure or underplay the structural fault-lines which have precipitated periodic crisis and intermittent collapse of the process.

I argue that a forensic analysis suggests that 'routine existential' crises 9 are, in fact, a consequence of sustained regression on fundamental aspects of the 1998 GFA. ${ }^{10}$ The application of a 'gender lens' to the process of implementation enables the identification of substantive attrition and claw-back.

\section{Criteria for evaluation}

In order to evaluate the Northern Ireland transition, I use an analytical framework synthesised from the work of Bell ${ }^{11}$ and Chinkin. ${ }^{12}$ Bell posits that peace processes can usefully be disaggregated to reveal three stages; pre-negotiation, framework/substantive and implementation agreements.

Chinkin refines Bell's model, further proposing 'questions of substance' which should frame a gender analysis of framework agreements. Gender analysis must be specifically applied to human rights guarantees, security and political participation. ${ }^{13} \mathrm{I}$ evaluate 'specimen' commitments made in the GFA within these thematic parameters, as illustrative in assessing the transition from a gender perspective.

\section{Human rights}

Parties' affirmation on the 'the right of equal opportunity in all social and economic activity' in the GFA was given expression by s 75 of the 1998 Northern Ireland Act. The s 75 duty was exalted as 'unique and world leading,, ${ }^{14}$ earning the impressive moniker of 'single most extensive positive duty imposed in the UK'. ${ }^{15}$

The available evidence, however, indicates that the statutory equality duty has not delivered in respect of gendered inequality. Conversely, problems with implementation and regression may have actually compounded discrimination and inequality for the most marginalised women. Critiques of the duty cite institutional resistance as a key impediment. Theories range from the benign - attributing this to an inherently

8 Christine Chinkin, Peace Agreements as a Means for Promoting Gender Equality and Ensuring the Participation of Women - A Framework of Model Provisions' Expert Group Meeting (UN Division for the Advancement of Women', 10-13 November 2003) 3.

9 Malachi O’Doherty, 'Stormont Crisis: Why Did Sinn Fein Decide to Vote Against Welfare Bill' Belfast Telegraph (Belfast, 20 March 2015).

10 GFA (n 1).

11 Christine Bell, 'Women and the Problems of Peace Agreements: Strategies for Change' in R Coomaraswamy and D Fonseka, Peace Work: Women, Armed Conflict and Negotiation (Women Unlimited 2005).

12 Chinkin (n 8).

13 Ibid13-26.

14 Colm O Cinneide, Taking Equal Opportunities Seriously: The Extension of Positive Duties to Promote Equality (Equality and Diversity Forum 2003); Paul Chaney and Theresa Rees, 'The Northern Ireland Section 75 Equality Duty: An International Perspective' Annex A in Eithne McLaughlin and Neil Faris, The Section 75 Equality Duty: An Operational Review (NIO 2004).

15 Tanya Barnett Donaghy, 'Mainstreaming Northern Ireland's Participative Democratic Approach', paper presented to the Jubilee Conference of the Australasia Political Studies Association, Australian National University, Canberra 2002. 
conservative civil service resistant to innovation ${ }^{16}$ - to the more malign - suggestive of tolerance for the promotion of equality further down the food chain, but resistant to implementation at the top. ${ }^{17}$ Certainly, when it comes to the decisions with significant resource implications, there is ample evidence of systematic failure to subject policy to full impact assessment. What is beyond dispute is the stark fact that no significant budget lines have been re-profiled or adjusted as a result of identified gender impacts.

Problems with implementation have been further compounded by a reassertion of a controversial community relations paradigm. ${ }^{18}$ Section $75(2)$ of the duty imposes a 'lesser'19 obligation to have regard for the need to promote good community relations. The common practice of government, to treat as equivalent sub-ss 75(1) and (2) has rendered objective need subservient to a need to maintain good relations and militated against the very type of redistributive action necessary for the delivery of equality in real terms.

Section 75 has also been critiqued on the basis of a failure to be responsive to intersectionality of discrimination in the lives of women and, in particular, its failure to acknowledge the distinct interplay of gender, religious belief and political opinion which exists in Northern Ireland. ${ }^{20}$ Evidence of a worsening situation in terms of the intersectionality of women's inequality can be adduced from statistics of housing need in North Belfast. Women most impacted by social housing inequalities are statistically more likely to be lone parents, have less disposable income and less control over family income. They constitute the 'low paid and unofficial labour market'. ${ }^{21}$ Catholics represented 73 per cent of those on waiting lists, but only 35.7 per cent of those awarded accommodation, whereas Protestant applicants constituted 26.2 per cent of the waiting lists but represented 64 per cent of those offered accommodation. ${ }^{22}$ The stark nature of these statistics has been of sufficient import to draw the attention of the UN Committee on Economic, Social and Cultural Rights. ${ }^{23}$ There have been suggestions that non-governmental organisations and women's groups may be consciously avoiding intersecting religious and political inequalities in reports and lobbying as a tactical approach to their own survival. ${ }^{24}$ Funding and broad-based appeal may be jeopardised where groups are perceived as divisive, overtly political or departing from the narrative of 'balance'.

\section{Security}

The application of a gender lens to issues of women's security in post-GFA Northern Ireland is very revealing.

16 Christopher McCrudden, 'Mainstreaming Equality in Northern Ireland 1998-2004: A Review of Issues Concerning the Operation of the Equality Duty in Section 75 of the Northern Ireland Act 1998', Annex B in McLaughlin and Faris (n 14).

17 Martin O’Brien, 'Section 75: A View from the Community and Voluntary Sector' in McCrudden (n 16).

18 See 'Unequal Relations? Policy, the Section 75 Duties and Equality Commission Advice: Has "Good Relations" Been Allowed to Undermine Equality?' Committee on the Administration of Justice (CAJ), May 2013, Belfast.

19 The legislation as drafted is particularly clear that s 75(1) is the primary duty, evidenced by the use of the phrase 'due regard' in opposition to the weaker obligation of 'regard' which is the language of the secondary duty outlined in s 75(2).

20 Eilish Rooney, 'Women's Equality In Northern Ireland's Transition: Intersectionality in Theory and Place' (2006) 14 Feminist Legal Studies 353.

21 Mary Daly, 'Women and Poverty' (Attic Press 1989); Eilish Rooney and Aisling Swaine, 'The "Long Grass" of Agreements: Promise, Theory and Practice' (2012) 12 International Criminal Law 545.

22 CAJ, Equality in Northern Ireland: The Rhetoric and the Reality (Shanways 2006); Rooney and Swaine (n 21).

23 Committee on Economic, Social and Cultural Rights, 'Concluding Observations of the Combined Fourth and Fifth State Party Report’ E/C.12/GBR/CO/5 12 June 2009.

24 Rooney and Swaine (n 21). 


\section{PHYSICAL SECURITY}

Arguably one of the most pressing risks to women's physical security and integrity is posed by intimate partner violence (IPV). McWilliams and Ni Aoláin note that IPV can actually increase in the post-conflict setting and may take on particular features as a result of access to legal and illegal weaponry. ${ }^{25} \mathrm{It}$ is imperative therefore that policy responses to IPV in the post-conflict institutional arrangements are robust and contextualised.

The Tackling Sexual Violence and Abuse Regional Strategy, ${ }^{26}$ however, has failed at the most basic level to acknowledge the transitional context and the particularities of the problem it ostensibly seeks to address. It further failed to identify and situate statutory responses within a human rights framework of state obligations. The effect of which, according to McWilliams and $\mathrm{Ni}$ Aoláin, was to situate individuals as 'pleaders for protection' rather than bearers of rights and status, as of right. ${ }^{27}$

The strategy's approach to domestic violence as 'irrespective of gender' has led to the capture of other forms of abuse, which can occur in the domestic setting. This composite approach has served to obscure the unequal power dynamics in intimate partner relationships, which form the kernel of the problem.

\section{LEGAL SECURITY}

The GFA considered policing and justice in the context of rights, safeguards and equality of opportunity. It commits to the establishment of an independent commission tasked with making recommendations for future policing arrangements. ${ }^{28}$ Compositional data indicated that 8 per cent of Royal Ulster Constabulary personnel identified as Catholic and only 13 per cent as female. Female officers were disproportionately over-represented in the part-time reserve and under-represented at senior levels. ${ }^{29}$ The Patten Commission report published in 1999, acknowledged the need for seismic compositional change towards representativeness. ${ }^{30}$

Section 46(1) of the Police Act 2000 facilitates 50/50 Catholic/Protestant quotas, whereas s 48 makes provision for a gender action plan aimed at increasing representation. The distinction in the two approaches taken to effect compositional change could hardly be starker. The religious differential was considered of significant political import to necessitate immediate introduction of quotas in order to effect rapid change to critical mass. The issue of unrepresentativeness in gender, however, was not similarly regarded, despite UK obligations under the Convention on the Elimination of all Forms of Discrimination Against Women and a recommendation from the then Equal Opportunities Commission. ${ }^{31}$ Upon the expiration of the temporary recruitment

25 Monica McWilliams and Fionnuala Ní Aoláin, 'There is a War Going on You Know: Addressing the Complexity of Violence Against Women in Conflicted and Post Conflict Societies' (2012) 1(2) Transitional Justice Review 2.

26 Tackling Sexual Violence and Abuse: A Regional Strategy 2008-2013 <www.dhsspsni.gov.uk/ tackling_sexual_violence_and_abuse_strategy.pdf $>$.

27 McWilliams and Ni Aoláin (n 25).

28 GFA (n 1) 'Policing and Justice', para 3.

29 Paddy Hillyard, Monica McWillaims and Margaret Ward, 'Reimagining Women's Security: A Comparative Study of South Africa, Northern Ireland and Lebanon' Northern Ireland Gender Audit (Economic and Social Research Council 2006) <www.wrda.net/Documents/NIGenderAudit.pdf>.

30 A New Beginning: Policing in Northern Ireland. The Report of the Independent Commission on Policing for Northern Ireland (NIO 1999) recommendation 112, para 14.17, recommendation 121, para 15.10

31 'Concluding Observations on the Seventh Periodic Report of the United Kingdom of Great Britain and Northern Ireland' (30 July 2012) CEDAW/C/GBR/CO/7 <www.ohchr.org/EN/hrbodies/cedaw/pages/ cedawindex.aspx>; and Hillyard et al (n 29). 
measures in 2010, women comprised 25.54 per cent of the Police Service of Northern Ireland and Catholic members made up 29.38 per cent. ${ }^{32}$

\section{Economic security}

Commitments made to tackle structural inequalities by law may prove as challenging as commitments made to secure political reform. ${ }^{33}$ Nowhere is this better exemplified than in the failure of the British government to establish a Bill of Rights for Northern Ireland. ${ }^{34}$

The Montréal Principles attest that economic, social and cultural rights have a particular significance for women. ${ }^{35}$ The principles further acknowledge that women's predisposition to socio-economic deprivation is compounded in conflict and postconflict settings. ${ }^{36}$ With the recognition that civil and political rights are largely justiciable by virtue of the 1998 Human Rights Act, ${ }^{37}$ women have the most to gain from the articulation of socio-economic rights within a Bill of Rights.

Following consultation with civic society, the Human Rights Commission, as mandated by the GFA, provided recommendations for a full suite of justiciable rights to constitute a Bill of Rights for Northern Ireland. ${ }^{38}$ The specified rights included economic and social rights. ${ }^{39}$ The creation of legally enforceable economic and social rights goes right to the core of the pervasive structural inequalities which subordinate women as 'lesser' and in this way have the potential to be truly redistributive. The Northern Ireland Office (NIO) unilaterally rejected the case for economic, social and cultural rights. ${ }^{40}$ The British government has since rendered the Northern Ireland Bill of Rights proposal hostage to an emerging debate in Britain, effectively sounding the death knell on the process. Analysis of comments made by state party representatives at the UK examination by the Committee on Economic, Social and Cultural Rights (CESCR) in 2009 are particularly revealing in establishing the policy of the current British government in respect of economic, social and cultural rights as constituting 'mere principles and values' and 'non justiciable'. ${ }^{41}$ Indeed, the current British government's commitment to repeal the 1998 Human Rights Act bodes ill for rights enhancement. At this juncture, regression on existing civil and political rights appears more likely.

32 Police (Northern Ireland) Act, 2000: Review of Temporary Recruitment Provisions (NIO 2011).

33 McCrudden (n 16) 520.

34 GFA (n 1) 'Rights, Safeguards and Equality of Opportunity: Human Rights', paras 4 and 5.

35 'Montréal Principles on Women's Economic, Social and Cultural Rights' (2004) 26 Human Rights Quarterly 760,761 .

36 Ibid.

37 Human Rights Act 1998.

38 Northern Ireland Human Rights Commission, 'Summary: A Bill of Rights for Northern Ireland' (Advice to the Secretary of State for Northern Ireland 2009).

39 Over 90 per cent of those polled believed it was 'very important' that a Bill of Rights contained economic and social protections: 'Submission from the Human Rights Consortium to the Northern Ireland Affairs Committee' May 2009 <www.publications.parliament.uk/pa/cm200809/cmselect/cmniaf/memo/ billofrights/ucm0602.htm?>.

40 NIO, ‘A Bill of Rights for Northern Ireland: Next Steps. A Consultation Paper' (Belfast November 2009).

41 CESCR, Concluding Observations E/C12GBR/CO/5 12 June 2009. 


\section{Political participation}

The GFA affirms the right of women to 'full and equal political participation'. ${ }^{42}$ In contrast to the myriad of provisions aimed at ensuring representation of the different political traditions, it contains no provisions which would give effect to this commitment.

Chinkin acknowledges that a peace agreement may provide for power-sharing, but be silent about women's participation in political structures. She observes, however, that 'provision for gender balance in the provisional administration will set the scene for the long term political participation of women'. ${ }^{43}$ This view is validated by Galligan's observation that the early pattern of women's exclusion here has become more difficult to address as the Assembly has bedded down. ${ }^{44}$ The absence of legal quotas from the framework agreement has been a defining structural inhibitor which has in practice resulted in a 'catch 22' situation where, unless more women are elected to the Assembly, it is unlikely to pass legislation to promote greater participation. ${ }^{45}$ Galligan notes that 'a more diverse legislature generates a more inclusive political agenda: the gendered impact of economic, health, family and educational policies are among the sectors that become open to debate leading to gender attuned policy outcomes'. ${ }^{46}$ The Sex Discrimination (Election of Candidates ) Act 2002 enables parties to voluntarily adopt measures to boost women's share of candidacy. The fact that women comprised only 28 per cent of those returned on foot of the 2016 Assembly Election indicates that parties have failed to do this in any meaningful way.

Acknowledging then the paucity of female representation in the political institutions and public life here in general, the concept of a Civic Forum provided an unparalleled opportunity to ensure that women could impact on the decision-making process. It was envisaged that representatives from a wide range of sectors, including the women's sector, would sit alongside the Assembly functioning as a consultative mechanism on social, economic and cultural matters.

The Civic Forum was suspended in 2002 with the devolved institutions. Unlike the other institutions provided for by the GFA, the Civic Forum was never re-activated. The recent 'Fresh Start' Agreement makes provision for a 'compact civic panel' of six members. Appointed directly by the First and Deputy First Ministers, they will be tasked 'to consider specific issues relevant to the Programme for Government'. ${ }^{47}$ This circumscribed 'intermediary' model is far removed from the model of participative governance envisaged by the GFA. Further and compelling evidence of the exclusion of women from the decision-making process at an institutional level is illustrated by the profile of the North's most senior civil servants; permanent secretaries who are exclusively male. ${ }^{48}$

42 GFA (n 1) s 6, para 1.9.

43 Chinkin (n 8).

44 Yvonne Galligan, 'Women in Politics and the Northern Ireland Assembly' Knowledge Exchange Seminar Series, Assembly and Executive Review Committee (NIA 2015) 1 <www.niassembly.gov.uk/globalassets/documents/official-reports/assembly-executive-review/20132014/140624_womeninpoliticsandtheniassemblyprofyvonnegalligan.pdf>.

45 Margaret Ward, 'Gender, Citizenship and the Future of the Northern Ireland Peace Process' (2005) 40(3/4) Eire-Ireland 1, 15 <http://www.cain.ulst.ac.uk/issues/women/docs/ward05peaceprocess.pdf>.

46 Galligan (n 44).

47 A Fresh Start: The Stormont Agreement and Implementation Plan (Northern Ireland Executive 17 November 2015).

48 S McCaffery and C Campbell, 'The Civil Servants Helping to Run Stormont's New Administration' thedetail <www.thedetail.tv/articles/the-civil-servants-helping-to-run-stormont-s-new-administration-f538097b-f9df4703-9d53-24ec9c60b361>. 


\section{UNSCR 1325}

A further obstacle to women's political participation has been the failure to implement UNSCR 1325 Women, Peace and Security (WPS). The resolution formally acknowledges women's right to participate in all aspects of conflict resolution and peace-building. The British government does not regard the conflict here as having met the definition of 'armed conflict' necessary to implement UNSCR 1325. As a consequence, despite being a society in transition from conflict, Northern Ireland has not been incorporated within the British government's National Action Plan.

A Westminster inquiry established to look at the implementation of the resolution received testimony from women which revealed that pressure was being applied to women at community level not to 'rock the boat'. ${ }^{49}$ It was repeatedly put to the panel that in the absence of 'appropriate and robust' interventions, regression was inevitable. ${ }^{50}$

The Committee for the Elimination of Discrimination Against Women has expressed concern at the low representation of women in the post-conflict process as a consequence of failure to implement UNSCR 1325 in Northern Ireland. ${ }^{51}$ By virtue of its innovative General Recommendation 30 on Women in Conflict Prevention, Conflict and Post Conflict Situations, it has offered the prospect of fusing the UN Security Council WPS Agenda with its own periodic reporting mechanisms in a way which does not directly engage international humanitarian law. ${ }^{52}$

\section{Conclusion}

The Northern Ireland transition was distinct from the majority of international peace processes in that women were included in the initial phases and, as a result, were able to impact upon the nature of the negotiation process and framework agreement in ways which yielded potentially far-reaching equality and human rights commitments. Those commitments, however, have failed to be consolidated in the process of implementation which has followed. At each successive stage, the implementation process has become more exclusive and the agenda has narrowed considerably, largely at the expense of those measures with inherent transformative potential.

While power-sharing and consociational arrangements undoubtedly provide stability in transitions from violent conflict, the Northern Ireland experience suggests that they may also constrain deeper aspects of political transformation. ${ }^{53}$ Brown and Ni Aoláin observe that 'while power sharing models offer the illusion of a transformed political landscape, in practice, for women the patterns of exclusion function in deeply similar ways'. Women's demand for equality of status has been largely sidelined by politicians and civil servants, who continue to prioritise central power issues and maintaining co-

49 Elizabeth Law and Ann Marie Gray, 'The Politics of Defining “Armed Conflict” in Northern Ireland' Open Democracy (26 June 2014) <www.opendemocracy.net/5050/elizabeth-law-ann-marie-gray/politics-ofdefining-armed-conflict-in-northern-ireland $>$.

50 Ibid.

51 Committee on the Elimination of Discrimination Against Women, 'Concluding Observations on the Seventh Periodic Report of the United Kingdom of Great Britain and Northern Ireland' CEDAW/c/GBR/CO/7 30 July 2013.

52 General Comment on Women in Conflict Prevention, Conflict and Post-Conflict Situations, 18 October 2013 CEDAW/C/GC/30 <www.ohchr.org/Documents/HRBodies/CEDAW/GComments/ CEDAW.C.CG.30.pdf $>$.

53 Kris Brown and Fionnuala Ní Aoláin, 'Through the Looking Glass: Transitional Justice Futures through the Lens of Nationalism, Feminism and Transformative Change' (2014) International Journal of Transitional Justice 1-23. 
operation between the two main Nationalist/Unionist blocs. Since the GFA, there have been a succession of further negotiations and agreements. Each of these agreements has been precipitated by political crises arising from outstanding commitments and/or allegations of default. Issues have included the impasse over the transfer of policing and justice functions, allegations of armed group activity and problems within the powersharing architecture. ${ }^{54}$ Ongoing default in respect of the key equality and human rights provisions has not, of itself, been regarded as sufficiently important to precipitate a crisis within the Stormont body politic. On the contrary, in each successive negotiation since 1998, equality and human rights elements have been eroded with consistency and power issues aggrandised.

The Stormont House Agreement last January collapsed all of the GFA commitments in respect of rights, safeguards and equality of opportunity into one catch-all, generic paragraph. 55

The attrition of inclusivity has eventuated in a process with questionable legitimacy. In this context, issues of culture, rights and legacy will remain pernicious in the absence of a gender-inclusive process which is grounded firmly in principles of human rights, substantive equality and governance. Eighteen years on from 1998, the promise of the 'full and equal participation of women' may now be even more elusive than it was then.

54 A Fresh Start (n 47).

55 Para 69, Stormont House Agreement: 'Noting that there is not at present consensus on a Bill of Rights, the parties commit to serving the people of Northern Ireland equally, and to act in accordance with the obligations on government to promote equality and respect and to prevent discrimination; to promote a culture of tolerance, mutual respect and mutual understanding at every level of society, including initiatives to facilitate and encourage shared and integrated education and housing, social inclusion, and in particular community development and the advancement of women in public life; and to promote the interests of the whole community towards the goals of reconciliation and economic renewal.' 